\title{
Resenha de: Rosa, Carlos Eduardo Valle, 2014. Poder Aéreo - Guia de Estudos. Rio de Janeiro: Luzes.
}

Rev. Bra. Est. Def. v. 4, $n^{\circ}$ 1, jan./jun. 2017, p. 259-261

DOI: $10.26792 /$ RBED.v4n 1.2017.72847

ISSN 2358-3932

\section{ANDERSON MATOS TEIXEIRA}

Os estudos sobre o Poder Aéreo na academia brasileira ainda são incipientes, não existindo mais do que meia dúzia de pesquisadores que focam no tema. A maior parte da produção fica restrita aos pensadores da Força Aérea Brasileira (FAB). Neste sentido, a produção vem a calhar, por trazer não só o debate internacional para o Brasil, mas também por difundir o campo de estudos.

No Brasil, temos uma dificuldade de acesso a fontes de estudo sobre Poder Aéreo, pela grande maioria dos pensadores ser estrangeira e do desconhecimento e barreiras existentes sobre a base nacional. Boa parte do encapsulamento do pensamento nacional vem da resistência da Força Aérea Brasileira em permitir o acesso a fontes e pelas restrições que a atividade militar que ela desempenha impõe.

Por esses motivos, a obra apresenta seu mérito por reunir, em uma obra, uma série de pensadores e os principais pontos sobre Poder Aéreo. A obra está dividida em quatro capítulos, além da introdução e conclusão, abordando os seguintes pontos em ordem organizacional: Ideias, conceitos e teorias sobre Poder Aéreo; Princípios de guerra aplicáveis à guerra aérea; Características do Poder Aéreo; e Funções do Poder Aéreo.

No capítulo 1, o autor apresenta uma coletânea de pensadores do Poder Aéreo, desde Douhet a Robert Pape, explanando sobre a biografia e o pensamento dos autores. Um ponto muito interessante é a inclusão dos pensadores brasileiros, como Nelson Freire Lavanère-Wanderley, Deoclécio Lima de Siqueira e Murillo Santos, importantes intelectuais da FAB. Carlos Eduardo foca nos pensadores clássicos ocidentais, principalmente os de origem estadunidense. Por mais que o autor aborde, de modo singelo, sobre pensadores de outras origens, eles são vistos superficialmente, principalmente os casos soviético-russo, chinês e israelense.

Passando para a segunda parte, o autor aborda sobre os princípios de guerra aplicados ao contexto da guerra aérea, como economia de forças, exploração dos êxitos, flexibilidade e versatilidade, manobra, massa, con-

Anderson Matos Teixeira - PPGCP-UFRGS/CEGOV e UFFS-Curso de Geografia-Erechim. 
centração de força, moral, objetividade, prontidão, segurança surpresa, sustentabilidade, caráter ofensivo, unidade de comando. Estes pontos norteiam o emprego do Poder Aéreo. Um ponto que se destaca é que o autor coloca como primeiro princípio cooperação, efeitos sinérgicos, apoio mútuo, sincronização, algo que muitas vezes passa despercebido por diversos autores, como Seversky e Pape, onde afirmam que só Poder aéreo seria capaz de vencer guerras, o que se constatou como inverdade. Carlos Eduardo traz como primeiro princípio a questão dos esforços conjuntos das forças singulares, onde elas devem atuar em conjunto com objetivos convergentes.

A terceira parte explora as vantagens e desvantagens da aviação em combate como alcance, altura e altitude, logística, carga útil limitada, custos elevados, flexibilidade, fragilidade, agilidade, necessidade de comando e controle, inteligência e as capacidades de penetração, precisão, velocidade e tecnologia. $\mathrm{O}$ autor ainda avança um pouco sobre o Poder Espacial. No caso, a figura do avião, como elemento principal do Poder Aéreo, apresenta pontos positivos e negativos em relação ao seu emprego, demandando um estudo bem aprofundado de relação custo e benefício, bem como a capacidade de projeção de poder de longo alcance, concatenando com o capítulo seguinte.

No capítulo 4, o autor aborda as funções que o Poder Aéreo desempenha, como superioridade aérea, operações aeroestratégicas, interdição, apoio aéreo aproximado, mobilidade aérea, consciência situacional e suporte ao combate. Neste ponto, observamos a característica principal da obra, onde o autor faz, mesmo que indiretamente, uma amarração dos pontos abordados anteriormente, com o objetivo de emprego do Poder Aéreo.

No geral a obra é muito interessante, por abordar vários aspectos relativos ao pensamento de Poder Aéreo. O foco do livro é a questão do emprego militar do Poder Aéreo. Pode-se perceber que este enfoque advém da formação do autor. Por ele ser oficial da Força Aérea Brasileira e instrutor da escola de altos estudos daquela força, isso traz um olhar para a instituição, no sentido de que ele apresenta muito do que a FAB utiliza em sua doutrina, como princípio e funções, justificando o pensamento da instituição. Faz-se necessário mencionar que esta obra tem alguns pontos de ineditismo, como trazer à tona que a FAB possui um corpo de pensadores.

Pelo autor focar no emprego do Poder Aéreo, ele deixa de lado a estruturação do Poder, não abordando um componente essencial à manutenção da capacidade de emprego: indústria, ciência e tecnologia. Em inúmeros episódios de emprego do Poder Aéreo, o fator capacidade de produção e desenvolvimento foram cruciais. Por mais que o autor cite a característica tecnologia, ele aborda a dependência tecnológica que a aviação demanda. Logo, pensar na estruturação do Poder Aéreo também é essencial. Sem o 
suporte da indústria, ciência e tecnologia, em caso de emprego, o Poder Aéreo pode ser fragilizado, principalmente devido a dependência de material de outros países. Esta questão da estrutura do Poder também é observada no debate Poder Marítimo versus Poder Naval.

Outro ponto interessante da obra, é que, por mais que o autor tenha construído esta obra para a instituição a que é vinculado, ele problematiza várias partes, para que o leitor, mesmo leigo, compreenda como são desdobrados os conceitos, funções e características, com casos históricos. Isso também é pautado pela formação do autor, como pedagogo na academia militar. Por ter a característica de ser didático, Carlos Eduardo procura demonstrar que há uma singularidade nas forças aéreas do mundo, ao comparar uma série de elementos e características de doutrinas e documentos que norteiam as forças aéreas.

Essa questão traz consigo o ponto de que cada nação estrutura seu Poder e este é um constructo social, refletindo em como são concebidas as normas e as próprias forças aéreas. Isso demonstra que os estudos que decorrem da análise do Poder Aéreo possuem uma série de variáveis a serem levadas em conta, refletindo por um ponto a necessidade de se ter pesquisadores com um domínio profundo e também um maior número de centros de pesquisa.

A obra é pioneira, sob certos aspectos, e por isso tem seu mérito. Seu objetivo não é ser a versão definitiva ou a enciclopédia do Poder Aéreo. Isso também reflete na necessidade de termos mais pensadores acadêmicos sobre o tema, bem como estruturas para o desenvolvimento de pesquisa e assessoramento dos órgãos que estruturam, como preconiza a Escola Superior de Guerra, o Poder Nacional, principalmente das estruturas militares. Ainda mais os referentes ao Poder Aéreo. É uma excelente obra para quem está interessado em compreender mais o emprego de Poder Aéreo. Ainda, obra de grande interesse para quem quer adentrar aos Estudos Estratégicos e de Defesa e para quem quer entender a evolução da FAB.

Palavras-chave: Forças armadas; poder aéreo; estudos militares. 